\title{
Electoral Fraud in Nigeria: A Philosophical Evaluation of the Framework of Electoral Violence
}

\author{
Ani Casimir, Emma Omeh, Chinedu Ike \\ Department of Philosophy/Institute of African Studies/Political Science, University of Nigeria, Nsukka, Nigeria \\ Email: cepperngo@yahoo.com, drommema@yahoo.com, chinedu-ike@hotmail.com \\ Received June $6^{\text {th }}$, 2013; revised August $4^{\text {th }}$, 2013; accepted August 21 $1^{\text {st }}, 2013$ \\ Copyright (C 2013 Ani Casimir et al. This is an open access article distributed under the Creative Commons At- \\ tribution License, which permits unrestricted use, distribution, and reproduction in any medium, provided the \\ original work is properly cited.
}

\begin{abstract}
In the 2011 general elections in Nigeria, the Independent National Election Commission (INEC), the electoral management body (EMB) that organized the elections pulled what may pass as an electoral feat in achieving one of the most open, credible, peaceful and transparent elections within Nigeria's recent memory. Before the 2011 elections, Nigeria had the 1999, 2003 and the 2007 elections considered by both national and international election observers, the Common Wealth Election Monitoring groups and the civil society, to be the most disorganized and fraudulent election during which people's votes were blatantly stolen, rigged and the mandate of the people hijacked by political elites belonging variously to different political parties. Nigeria's democracy, no doubt, is still nascent, evolving and could be classified as a new democracy. This paper takes a critical look at a disturbing national and international question: why is there so much electoral fraud in new and emerging democracies like Nigeria. The article seeks to establish the reasons and causes of electoral manipulation, its dynamics and corrupt tendencies, especially those electoral outcomes that are disputed as a result of electoral misconduct known as "electoral fraud". The article will evaluate the concept of electoral fraud, explore the challenges of electoral fraud, its consequent crisis for new democracies and suggests ways of curtailing the phenomenon in its varied manifestations.
\end{abstract}

Keywords: Philosophy of Good Governance; Electoral Fraud; Political Elites; Election Management Body and Nigeria; Democratic Governance for Development Project; Pillars of Democracy

\section{Introduction}

An electoral fraud is seen as an illegal interference with the process of election that interferes with the mandate of the people. Other features of this political elite fraud include:

1) Using vote counts to change an election result;

2) Increasing the number of votes for the favored candidate;

3) Reducing the vote share of the opposing candidates or parties.

In Nigeria's chequered political and democratic history, special dimensions were assumed by the country's electoral fraud experience to include:

4) Under age voting;

5) Mass voting by unregistered citizens (neither qualified to register nor even registered to vote);

6) Snatching of ballot boxes to be stuffed with thumbprinted votes for party candidates;

7) Switching of results before or after collation to favor ruling party candidates;

8) Intimidation at the polls using private militant gangs or even state security;

9) Scaring away of genuine registered voters from exercising their votes in polling booths located in an opposition favored constituency;

10) Deliberate, one-sided and improper counting of votes;

11) Media manipulation to announce or publish the wrong results and the wrong candidates as winners before the proper collation of results by the Electoral Commission.

Since this study focuses on electoral fraud in Nigeria, as a fundamental cause and framework under which electoral violence is unleashed that threatens the political order and peace in Nigeria, it will be a vital and relevant good step to give a summary background of recent Nigeria's relevant political and democratic history.

\section{Background History of Recent Democractic Experience in Nigeria}

Nigeria is a country with diverse and multifarious culture with overlapping regional, religious, and ethnic boundaries. Nigerian's present population is estimated to be around 150 million. With the emergence of democratic politics in 1999 after over thirty (30) years of military rule, elections took place in Nigeria with candidates contesting on different political platforms for the presidency, the national Assembly, State Houses of Assembly, and governorship in the 36 states. The hope raised by the enthusiasm with which the country embraced democratic process in 1999 was a false indicator an emerging stable democracy in Nigeria. The hope was misplaced as recent indicators will prove According to the report written on 2011 elections by the International Foundations for Election Systems (IFES) (Aniekwe \& Kushie, 2011) the hope raised by democ- 
ractic politics was dashed and the expectations continued to fall with bleak prospects:

Since the 1999 to the 2007 elections, the Nigeria electoral and political landscape has fallen from par to below par and has moved from violence to greater violence. The level and magnitude of electoral and political violence has risen and the political elites have often converted poverty ridden unemployed Nigerian youths into readymade machinery for the perpetration of electoral violence. This is linked to the political system and institution that in theory has failed to political participation and in practice has seen the political elites forming bulk of the sponsors and perpetrators of electoral violence. An examination of the political antecedents reveals evidence of political and electoral violence in Nigeria before 1999. There were repeated scales of violence and political and/or religious rift between the Christian and Muslim on the one side and North and South on the other side. The pattern of violence in the former is such that cut across political, sectarian and electoral, while in the latter, the activities of the militant (so called freedom fighters) transcends just the struggle for the control of the resources to include both covert and overt participation in perpetrating electoral violence ${ }^{1}$.

The configuration of the Nigeria political system falls along six geopolitical zones namely: the North viz: the North-West comprising Kaduna, Katsina, Jigawa, Sokoto, Kebbi, Kano, and Zamfara; the North-East comprising Bauchi, Gombe, Borno, Taraba, Adamawa and Yobe; the North Central comprising Plateau, Nassarawa, Niger, Kwara, Kogi and Benue. In the South, the geopolitical configurations are the South-West comprising Lagos, Osun, Ogun, Oyo, Ekiti and Ondo; the SouthEast comprising Enugu, Anambra, Imo, Abia and Ebonyi and the South-South comprising Rivers, Cross River, Akwa Ibom, Delta Edo and Bayelsa. None of these zones is spared from possibility of electoral violence nonetheless; the trigger, machinery and strategy employed might differ and the remote cause may as well vary across zones and states.

\section{Electoral Fraud and Violence-A Dialectical Link}

Electoral violence in Nigeria is caused by electoral fraud and manipulation of figures and data to deny the rightful winners their popular mandates given to them and certified by the electoral process. It is an attempt to willfully compromise the integrity of the electoral process or system to achieve unmerited individual win for a political party candidate through the falsification of the electoral figures, numbers, data or process. Electoral fraud is the organized strategy or programs of individuals and or political parties to get desired results of an electoral process either by hook (or) crook. It is the number one cause of electoral violence before, during or after elections.

\section{Electoral Violence}

Researches on electoral violence is scare and often times focuses broadly with a mixture of political and electoral violence. However some scholars have made attempt to conceptualise electoral violence (Aniekwe \& Kushie, 2011). As quoted by Aniekwe and Kushie, Fischer defined electoral violence (conflict) as "any random or organized act that seeks to determine, delay, or otherwise influence an electoral process through

${ }^{1}$ Chika Charles Aniekwe \& Joshua Kushie (2011): Electoral Violence Situational Analysis: Identifying Hot-Spots in the 2011 General Elections in Nigeria, Joint Association For Peaceful Elections in Nigeria and IFES p. 1. threat, verbal intimidation, hate speech, disinformation, physical assault, forced 'protection', blackmail, destruction of property, or assassination" ${ }^{2}$. On his part Otigbe Igbuzor (2010) views it as:

"any act of violence perpetuated in the course of political activities, including pre, during and post election periods, and may include any of the following acts: thuggery, use of force to disrupt political meetings or voting at polling stations, or the use of dangerous weapons to intimidate voters and other electoral process or to cause bodily harm or injury to any person connected with electoral processes" ${ }^{3}$.

The work of Fischer, according to Anikwe \& Kushie (2011) "culminated into a comprehensive research by the International Foundation for Election Systems (IFES) on electoral violence, which later set the state for the Electoral Violence Education and Resolution (EVER) project that has been implemented in countries across continents including Ghana, Kyrgyzstan, Guyana, Iraq, East-Timo and Nigeria. The EVER project is currently being implemented in Nigeria and it presents a comprehensive and robust understanding of the context and concept of electoral violence". Within the EVER framework therefore election-related violence refers to

"any violence (harm) or threat of violence (harm) that is aimed at any person or property involved in the election process, or at disrupting any part of the electoral or political process during the election period" 4 .

The three definitions, closely related, capture the stages of electoral violence as well as the actors constitute electoral violence. It is this morphology and deeper nature of electoral violence with its causes that Anikwe and Kushie again analysed with interconnections to electoral fraud:

The crucial thing is that the definitions reveal the deeper nature of electoral violence in a way that readers would understand that electoral violence is much more than Election Day violence or overt manifestation of violence during election period. It transcends that to capture the election stages and can be a harm or threat to harm to the electoral process. Election violence generally involves political parties, their supporters, journalists, agents of the government, election administrators and the general population, and includes threats, assault, murder, destruction of property, and physical or psychological harm ${ }^{5}$.

This dialectical observation is closely related to the conceptualization of political and electoral related violence in a cross country study of post World War II political violence, in which Hibbs (1973) took a broader approach to capture the entire periods of election process. By these definitions, it becomes clear why our understanding of electoral violence must involve specific victim(s), perpetrator(s) and occurs within a time frame and location. These perpetrators come with their fraudulent motives and the victims of electoral violence are people, places, things or data which are often manipulated, distorted or destroyed. This presupposes that electoral violence cuts across different stages of election starting from the registration period to post election period. Fischer (2002) highlighted four descriptive categories of conflict and violence that emerge, suggesting a variety of motives, perpetrators, and victims which includes the following:

\footnotetext{
${ }^{2}$ Fisher, Electoral Violence culled from Aniekwe \& Kushie (2011).

${ }^{3}$ Otigbe Igbuzor culled from Kushie (2011:18).

${ }^{4}$ Electoral Violence (EVER Project; International Foundation for Elections System Paper, 2011).

${ }^{5}$ Fisher (2002) International Foundation for Elections system Report.
} 
1) Disgruntled voters against the state arising from perceived unfairness in the election process;

2) The state in conflict with voters who challenges election result or hegemony of the state;

3) Political rivals in conflict with each other in the quest to attain power and;

4) A combination of two or more of the above categories"6.

From the above we can see that it is a given that electoral fraud is at the heart of electoral violence because people, as electorates and stakeholders in a countrry's democracy, are not happy when their electoral and democratic rights had been stolen either before, during or after elections had taken place. Violence is one of the reactions to electoral victory denial, real or perceived. Electoral fraud when properly documented by election monitors confirms the fact that a particular election or electoral process has not been transparent, fair or credible to make the peoples' votes to count or to genuinely reflect their democratic mandate.

No matter the cultural shape of electoral fraud or whatever the violent reactionary dimension it has assumed in Nigeria (Or anywhere else), what has become fixed in the conceptual framework of electoral best practices is that electoral misconduct and corruption differs from country to country, under different laws, that define what it is, its national and local tenor. Many electoral laws define what constitutes violation of good conduct before, during, and after elections. But as in Nigeria (until 2011) the good electoral laws made by its National Assembly turn a blind eye to massive rigging and violence with impunity because of weak institutions that are easily manipulated by politicians. Although technically the term "electoral fraud" covers only those acts which are illegal, the term is sometimes used to describe acts which although legal, are considered to be morally unacceptable, outside the spirit of electoral laws or in violation of the principles of democracy ${ }^{7}$.

In the context of political theory it is accurate to state that electoral fraud violates both the spirit and laws of democracies. According to John Locke, considered rightly as the theoretical architect of democracy as it exists in the world today ${ }^{8}$ clearly states that in a free society (democracy) "no one ought to harm or cheat another of his life, health, liberty and possession"”. Any government based on this principles of misconduct will be unstable, chaotic and tyrannical since it "operates by caprice, and the society it controls will be correspondingly unstable" ${ }^{\text {"10 }}$. According to Locke:

In a properly conducted government, a democracy such a state of affairs will be ruled out. Democracy is government by laws that are arrived at after long deliberation by properly chosen representatives of the people ${ }^{11}$.

\footnotetext{
${ }^{6}$ Fisher (2002:3).

${ }^{7}$ Fisher.

${ }^{8}$ Popken and Sholl (1993/70) The political philosophy of John Locke, New York): In the context of political theory it is accurate to say that electoral fraud violates both the spirit and laws of democracies. According to John Locke, considered rightly as the theoretical architect of democracy as it exists in the world today clearly states that in a free society (democracy) "no one ought to harm or cheat another of his life, health, liberty and possession". ${ }^{9}$ Popken and Sholl (1993/71) The political philosophy of John Locke.

${ }^{10}$ Popken and Sholl (1993/72) The political philosophy of John Lock: Any government based on this principles of misconduct will be unstable, chaotic and tyrannical since it "operates by caprice, and the society it controls will be correspondingly unstable”.

${ }^{11}$ Popken and Sholl (1993/PP 74-76) The political philosophy of John Locke According to Locke: "In a properly conducted government, a democracy such a state of affairs will be ruled out. Democracy is government by laws that are arrived at after long deliberation by properly chosen representatives of the people".
}

Electoral fraud, cheating, violence rigging or manipulation of votes either by INEC or ruling parties either at the national, state or local government levels in Nigeria is sharply at variance with the democratic rights and freedoms of Nigeria people, it is therefore a fundamental violation of the constitution and liberty of Nigerians whose electoral mandates were stolen.

\section{Considerations and Evaluation of Different Electoral Frauds in a Democracy}

As can be seen from the picture of electoral fraud experience in Nigeria, it is differs from country to country and has different national laws establishing, defining and sanctioning what constitutes electoral fraud, its violations and sanctions. In Nigeria's flawed electoral process and history electoral fraud has had the negative impacts on her people at the same level coups and corruptions have weakened the country's development. This is because the electoral frauds not only were not only unpunished but beneficiaries of electoral frauds were supported by government institutions to form new governments and let in parliaments at the national, state and local levels after the elections. When people's mandates are short changed and the electoral fraud with its perpetrators not punished, it can reduce voters confidence in a democracy, government and reduce their support for institutions that strengthen democratic participations.

\section{Morphology of Electoral Fraud-A Universal Perspective}

The nature and symptoms of electoral fraud that is seen in Nigeria draws from a universal perspective and definition that attempts to establsih some working principle of what has been variously described as political and democratic corruption. This is because electoral fraud is an illegal interfrence in the transparent process of an election. Accordingly, a working gleaned from the Global Research website, Wikipaedia, defines electoral fraud as an incident that not only destabilizes a democracy but it could also put an election process into a credibility crisis making it difficult for people and voters not to accept an election process or its results:

"Electoral fraud is an illegal interference with the process of an election. Acts of fraud affect vote counts to bring about an election result, whether by increasing the vote share of the favored candidate, depressing the vote share of the rival candidates or both. Also called voter fraud, the mechanisms involved include illegal voter registration, intimidation at polls and improper vote counting. What electoral fraud is under law varies from country to country. Many kinds of voter fraud are outlawed in electoral legislation but others are in violation of general laws such as those banning assault, harassment or libel. Although technically the term 'electoral fraud' covers only those acts which are illegal, the term is sometimes used to describe acts which although legal, are considered to be morally unacceptable, outside the spirit of electoral laws or in violation of the principles of democracy"12.

In national elections, successful electoral fraud can have the effect of a coup d'état or corruption of democracy. In a narrow election a small amount of fraud may be enough to change the result. If the result is not affected, fraud can still have a damaging effect if not punished, as it can reduce voters' confidence in

\footnotetext{
${ }^{12}$ The Spirit of Electoral Laws or Violation of the Principles of Democracy (www.wikipaedia.com).
} 
democracy. Even the perception of fraud can be damaging as it makes people less inclined to accept election results. This can lead to the breakdown of democracy and the establishment of a dictatorship. Electoral fraud is not limited to political polls and can happen in any election where the potential gain is worth the risk for the cheater; as in elections for labor union officials, student councils, sports judging, and the awarding of merit to books, films, music or television programmes. Despite many instances of electoral fraud, it remains a difficult phenomenon to study. This follows from its inherent illegality. Harsh penalties aimed at deterring electoral fraud make it likely that individuals who perpetrate fraud do so with the expectation that it either will not be discovered or will be excused ${ }^{13}$.

\section{The Democratic Governance for Development Project in Nigeria}

Electoral fraud in Nigeria has served the ignoble purposes of weakening the people's confidence and support for democratic institution in Nigeria. Institutions of democracy strengthen and stabilize democratic development since they encourage and legalize wider popular participation in the democratic and development process. As a result of the several decades of organized electoral fraud perpetrated at the national, state and local levels of governance people have lost faith in governance, institutions and experienced mass alienation and exclusion from the process of governance. This has weakened the development programs, projects and prospects of Africa's most populated country. The huge electoral fraud committed during the 2007 elections made the European Union, the Commonwealth and the United Nations Development Program (UNDP) to carry out a detailed study of the pervasive problem of why Nigerians have lost interest, confidence and faith in democratic institutions $^{14}$. (The DGD sponsored survey) and came to the conclusion that the pillars of democracy in Nigeria are weak and, as a result, electoral manipulation and fraud are used to truncate the popular mandate and wishes of the people.

To strengthen democracy in Nigeria democratic pillars such as the media, gender, the legislature, youths, the civil society and INEC needed to be enlightened and empowered with true democratic values to be able to place them at a pedestal they can be mobilized during elections to guard and protect the voters of people during and after elections. The democractic pillars will not only restore confidence in democratic institutions but will enable the votes of the Nigerian people to count. Supervised and managed under the United Nations Development Program (UNDP), the DGD project in Nigeria is jointly sponsored by the European Union, Canadian Agency for International Development, (Cida), the Department for International Development of the British Government (DFID), the Korean Agency for International Development (KOIDA) and the UNDP. The Nigerian Democractic Governance for Development Project (DGD) was targeted principally at checkmating the incidence of electoral fraud which has sabotaged Nigeria's democratic aspiration and progress. With the high level of

\footnotetext{
${ }^{13}$ Wikipaedia. Ibid.

${ }^{14}$ The huge electoral fraud committed during the 2007 elections made the European Union, the Commonwealth and the United Nations Development Program (UNDP) to carry out a detailed study of the pervasive problem of why Nigerians have lost interest, confidence and faith in democratic institutions. See: The DGD Project sponsored survey of participatory level of Nigerians in the country's democractic institutions and processes of election and development (2010), UNDP Nigeria website.
}

transparency, peace and fair polls witnessed in 2011 elections, the international and local observers and development partners may have been correct in giving credit to INEC Nigeria's new electoral management body under Professor Attahiru Jega checkmating historical incidences of electoral fraud. More importantly to be factored into this democratic credit mix is the positive impact and influence played by the DGD in Nigeria in restoring the electoral confidence of Nigerians in democratic institutions ${ }^{14}$.

\section{Tendencies and Tenacity of Past Electoral Frauds in Nigeria}

Inspite of many instances of electoral fraud as witnessed severally in Nigeria, it is a phenomenon difficult to study and checkmate. Perpetrators of electoral fraud in the country, despite new electoral laws meant to checkmate them, still perpetuate it and violate the electoral freedoms of Nigerians with impunity. They do so either with the expectation that the fraud will not be discovered by INEC, they may collude with willing INEC officials, police or if discovered, that they will go unpunished.

Before the success of INEC on the 2011 electoral feat, Nigeria was racked by a pervasive history of electoral fraud since independence. As agreed to by several scholars such as Patrick Iroegbu: 2003: 17, since 1960 when the country attained political independence from Brittan electoral fraud at a time became a disease ravaging Nigerian people and undermining their development planning, leading to a psychological phenomenon known as electoral fraud anger syndrome that disposes the cheated masses to violence:

Beyond any reasonable shade of doubt, there is a political illness that sweeps across Nigeria at any given election time since independence. This political illness is very contagious, disruptive and result to wrong choice of credible leaders to make development and healthy living occur. It has a name. We call it "severe Nigerian Electoral Fraud Anger Syndrome" (SNEFAS). The concept of this political illness is typically one characterized by devastating impact on people's thinking and emotional control each time it plays out. Has it mattered to know how many people died in the last concluded (2003) elections? The figure could be frightening. The electoral time bonus of a government sweeps people across to death once it is detonated. But how come choosing leadership in Nigeria can be so devastating?

It has become obvious that violence, savagery, kidnapping, vote stuffing ballot box snatching, bribery, and corruption of security/electoral agents and outright rigging out of rival political opponents were part of what constitutes electoral fraud in Nigeria. Police brutality and total disregard for human life and dignity connive to generate massive electoral malpractices in Nigeria during which youths and college students are used as political thugs, armed and sponsored by Nigeria's political elites and political parties who want to won at all costs. This article would not focus upon the history of electoral frauds in Nigeria nor upon what causes them. Some of the identified cultural shapes of Nigeria's electoral fraud had been identified in the introduction-we would go further for the purposes of clarity to expand the conceptual identification process of what constitutes electoral fraud not only in Nigeria but in other developing democracies. 


\section{Electoral Fraud Species in Developing Democracies}

Electoral fraud can occur at any stage in the democratic process, but most commonly occurs during election campaigns, voter registration or during vote-counting. The two main types of electoral fraud are preventing eligible voters from casting their vote freely (or voting at all); and altering the results. A list of threats to voting systems, or electoral fraud methods, especially its species that occur in developing democracies such as Nigeria is as follows:

\section{Manipulation of the Electorate}

Political elites seeking votes indulge in an unfair manipulation of the voting public through gerrymandering, demographic manipulation, outright disenfranchisement of registered voters, intimidation, vote buying (cash for votes), printing a confusing ballot papers that could mislead voters, stuffing of ballot boxes with illegally thumb printed votes, deliberate mis-recording of votes (it either increase for a favored candidate or decrease for an ill-favored opponent, abuse of proxy or electronic voting, or destruction and invalidation of genuine votes cast (or vice versa —validation of invalid votes).

\section{Legislative Vote Fraud}

It may be surprising to a lot of people that vote fraud in new and transitory democracies can also take place in the legislatures of such democracies.

\section{Electoral Fraud and Voting Machines}

Surprisingly, the technology used to refine and enhance participating value of the electoral process in both new and old democracies have become tools to expand the possibilities of electoral fraud, its un-dertection and increased use of technology is steal the people's mandate.

\section{Gerrymandering}

Gerrymandering is the drawing of electorate boundaries in order to produce a particular result. Typically, electorates will be organized so that one group of people (for example poor people or a particular ethnic or religious group) is concentrated into a small number of electorates. This means that parties favoured by that group will win by a large majority in those electorates, but lose more narrowly in a larger number of electorates. This may result in one party gaining the most votes overall but still losing the election. Gerrymandering is most common under plurality voting systems, in which the winner must win the most electorates rather than the most votes overall ${ }^{15}$.

\section{Manipulation of Demography}

In many cases it is possible for authorities to artificially control the composition of an electorate in order to produce a foregone result. One way of doing this is to move a large number of voters into the electorate prior to an election, for example by temporarily assigning them land or lodging them in shanty households. Another strategy is to permanently move people into an electorate, usually through public housing. If people eligible for public housing are likely to vote for a particular party, then they can either be concentrated into one electorate, thus making their votes count for less, or moved into marginal electorates, where they may tip the balance towards their pre-

\footnotetext{
${ }^{15}$ Understanding Gerrymandering - Threats to Voting Systems (NIST).
}

ferred party. A loose immigration law may also be used by a country to manipulate electoral demography that they secretly support. In 1983 and 2003, it was heavily suspected by the oposition parties that Nigeria's borders were thrown open by the ruling party at the centre to allow Nigeriens and Chadians to register as voters to vote during the elections, thus entering the country as illegal aliens who after the elections become threats to the peace and stability of the country ${ }^{16}$.

\section{Electorate Manipulation}

Most electoral fraud takes place during or immediately after election campaigns, by interfering with the voting process or the counting of votes. However it can also occur far in advance, by altering the composition of the electorate. In many cases this is not illegal and thus technically not electoral fraud, although it is sometimes considered to be a violation of principles of democracy $^{17}$.

In many cases gerrymandering occurs within, or is the result of, electoral law. However it may sometimes take the form of true electoral fraud, for example if laws governing the drawing of electoral boundaries are broken, or officials are bribed or otherwise coerced into altering boundaries in a way which favours a particular group.

\section{Disenfranchisement}

The composition of an electorate may also be altered by disenfranchising some types of people, rendering them unable to vote. In some cases this may be done at a legislative level, for example by passing a law banning convicted felons, recent immigrants or members of a particular ethnic or religious group from voting, or by instituting a literacy or other test which members of some groups are more likely to fail. Since this is done by lawmakers, it cannot be election fraud, but may subvert the purposes of democracy. This is especially so if members of the disenfranchised group were particularly likely to vote a certain way. In some cases voters may be invalidly disenfranchised, which is true electoral fraud. For example a legitimate voter may be "accidentally" removed from the electoral roll, making it difficult or impossible for them to vote. Corrupt election officials may misuse voting regulations such as a literacy test or requirement for proof of identity or address in such a way as to make it difficult or impossible for their targets to cast a vote. If such practices discriminate against a religious or ethnic group, they may so distort the political process that the political order becomes grossly unrepresentative, as in the postReconstruction or Jim Crow era until the Voting Rights Act of 1965. Groups may also be disenfranchised by rules which make it impractical or impossible for them to cast a vote. For example, requiring people to vote within their electorate may disenfranchise serving military personnel, prison inmates, students, hospital patients or anyone else who cannot return to their homes. Polling can be set for inconvenient days such as midweek or on Holy Days (example: Sabbath or other holy days of a religious group whose teachings determine that voting is a prohibited on such a day) in order to make voting difficult for those studying or working away from home. Communities may also be effectively disenfranchised if polling places are not provided within

\footnotetext{
${ }^{16}$ Williamson, Chilton (1968). American Suffrage from Property to Democracy. Princeton, NJ: Princeton U. Press. ASIN B000FMPMK6.

${ }^{17}$ Sadiq, Kamal (2005). When States Prefer Non-Citizens Over Citizens: Conflict Over Illegal Immigration into Malaysia (PDF). International Studies Quarterly, 49, 101-122.
} 
reasonable proximity (rural communities are especially vulnerable to this) or situated in areas perceived by some voters as unsafe $^{18}$.

\section{Intimidation}

Voter intimidation involves putting undue pressure on a voter or group of voters so that they will vote a particular way, or not at all. Absentee and other remote voting can be more open to some forms of intimidation as the voter does not have the protection and privacy of the polling location. Intimidation can take a range of forms.

1) Violence or the threat of violence: In its simplest form, voters from a particular demographic or known to support a particular party or candidate are directly threatened by supporters of another party or candidate or those hired by them. In other cases supporters of a particular party make it known that if a particular village or neighbourhood is found to have voted the "wrong" way, reprisals will be made against that community. Another method is to make a general threat of violence, for example a bomb threat which has the effect of closing a particular polling place, thus making it difficult for people in that area to vote ${ }^{19}$.

2) Attacks on polling places: Polling places in an area known to support a particular party or candidate may be targeted for vandalism, destruction or threats, thus making it difficult or impossible for people in that area to vote.

3) Legal threats: In this case voters will be made to believe, accurately or otherwise, that they are not legally entitled to vote, or that they are legally obliged to vote a particular way. Voters who are not confident about their entitlement to vote may also be intimidated by real or implied authority figures who suggest that those who vote when they are not entitled to will be imprisoned, deported or otherwise punished. For example, in 1999 elections, anonymous flyers were circulated that if people fail to vote for Retired General Obasanjo, the Nigerian military establishment might refuse, or in fact, rethink handing over to Chief Falae, the opposition presidential candidate; Obsanjo was projected as the military candidate being a former military Head of State of the country.

4) Economic threats: In company towns in which one company employs most of the working population, the company may threaten workers with disciplinary action if they do not vote the way their employer dictates.

\section{Vote Buying}

This is a common a common phenomenon in Nigeria's past electoral history. It is called "cash for votes" I call it the monetization or commercialization of the voting process and the conscience of the mostly poor voters. Voters may be given money or other rewards for voting in a particular way, or not voting. In some jurisdictions, the offer or giving of other rewards is referred to as "electoral treating"

\section{Misinformation}

People may distribute false or misleading information in order to affect the outcome of the election. Most commonly, smear campaigns (the circulation of false rumours) are made

\footnotetext{
${ }^{18}$ Joseph Grego, A history of parliamentary elections and electioneering in the old days (1886) pp. 226-28 online.

${ }^{19}$ Did bomb threat stifle vote? (Capital Times, May, 2010).

${ }^{20}$ Parliamentary Electorates And Elections Act 1912-Section 149, New South Wales Consolidated Acts.
}

against a particular candidate or party. Smear campaigns are not necessarily illegal and can therefore not always be considered election fraud. However in some countries smear campaigns may violate libel or slander laws and in others, as the Philippines, such campaigns are specifically illegal. Another way in which misinformation can be used in voter fraud is to give voters incorrect information about the time or place of polling, thus causing them to miss their chance to vote ${ }^{21}$.

\section{Misleading or Confusing Ballot Papers}

Ballot papers may be used to discourage votes for a particular party or candidate, using design or other features which confuse voters into voting for a different candidate. For example, in the 2000 US presidential election, Florida's butterfly ballot paper was criticised as confusing some voters into giving their vote to the wrong candidate. Ironically, however, the ballot was designed by a Democrat, the party most harmed by this design $^{22}$. Poor or misleading design is not usually illegal and therefore not technically election fraud, but can subvert the principles of democracy ${ }^{23}$.

\section{Ballot Stuffing}

Ballot stuffing occurs when a person casts more votes than they are entitled to. In its simplest form, ballot stuffing literally involves "stuffing" multiple ballot papers into the ballot box. Another method is for voters to cast votes at multiple booths, on each occasion claiming that it is their only vote. In some countries such as Nigeria, India, El Salvador, Namibia or Afghanistan voters get a finger marked with election ink to prevent multiple votes. In Afghanistan's elections of 2005, this method failed as the ink used could easily be removed. A more subtle technique is impersonation, in which a person pretends to be someone else. The person whose vote is being used may be legitimately enrolled but absent, a real but deceased person, or entirely fictitious. A particularly unsubtle form of ballot stuffing, known as booth capturing, sometimes occurs in India. In these cases a gang of thugs will "capture" a polling place and cast votes in the names of legitimate voters, who are prevented from voting themselves ${ }^{24}$.

\section{Misrecording of Votes}

Many elections feature multiple opportunities for unscrupulous officials or "helpers" to record an elector's vote differently from their intentions. Voters who require assistance to cast their votes are particularly vulnerable to having their votes stolen in this way. For example, a blind person or one who cannot read the language of the ballot paper may be told that they have voted for one party when in fact they have been led to vote for another ${ }^{25}$.

\footnotetext{
${ }^{21}$ Wisconsin Democratic voters targeted with Koch-funded absentee ballot notices advising them to vote two days after the recall election. 2 August 2011.

http://boingboing.net/2011/08/02/wisconsin-democratic-voters-targeted-wit h-koch-funded-absentee-ballot-notices-advising-them-to-vote-2-days-after-t he-recall-election.html

${ }^{22}$ Lacayo, Richard. "Florida recount: In the eye of the storm”. CNN. http://archives.cnn.com/2000/ALLPOLITICS/stories/11/13/recount.tm/inde x.html.

${ }^{23}$ Stealing Elections, Revised and Updated: How Voter Fraud Threatens Our Democracy/John Fund (2008) 224-226.

${ }^{24}$ Kiesling, John Brady, "Charting Electoral Fraud: Turnout Distribution Analysis as a Tool for Election Assessment” [2].

${ }^{25}$ hpilkin, Sergey, Mathematics of Elections-Vote Fraud Ruling Shifts Pennsylvania Senate New York Times, February 19, 1994.
} 


\section{Misuse of Proxy Votes}

Proxy voting is particularly vulnerable to election fraud due to the amount of trust placed in the person who casts the vote. In several countries there have been allegations of retirement home residents being asked to fill out "absentee voter" forms. When the forms are signed and gathered, they are then secretly rewritten as applications for proxy votes, naming party activists or their friends and relatives as the proxies. These people, unknown to the voter, then cast the vote for the party of their choice $^{26}$.

\section{Destruction or Invalidation of Ballots}

One of the simplest methods of electoral fraud is to simply destroy ballots for the "wrong" candidate or party. This is unusual in functioning democracies as it is difficult to do without attracting attention. However in a very close election it might be possible to destroy a very small number of ballot papers without detection, thereby changing the overall result. Blatant destruction of ballot papers can render an election invalid and force it to be re-run ${ }^{27}$.

\section{Vote Fraud in the Legislature}

Vote fraud can also take place in legislatures. Some of the forms used in national elections can also be used in parliaments, particularly intimidation and vote-buying. In many legislatures, voting is public, in contrast to the secret ballot used in most modern public elections. This may make their elections more vulnerable to some forms of fraud, since a politician can be pressured by others who will know how he or she has voted. However, it may also protect against bribery and blackmail since the public and media will be aware if a politician votes in an unexpected way. This method served in stopping former president Obasanjo from accomplishing his infamous " 3 rd term tenure elongation agenda" when, on the floor of the National Assembly, legislators, afraid of the recall powers of their constituents watching the tenure elongation debates in a live telecast, voted against that unconstitutional amendment sought by the former president o extend his presidency without popular or constitutional mandate.

\section{Electoral Fraud and Voting Machines}

All voting systems face threats of some form of electoral fraud. The types of threats that affect voting machines can vary from other forms of voting systems, some threats may be prevented and others introduced. Some forms of electoral fraud specific to electronic voting machines include: tampering with the software of a voting machine to add malicious code altering vote totals or favor any candidate; tampering with the hardware of the voting machine to alter vote totals or favor any candidate; or abusing the administrative access to the machine by election officials might also allow individuals to vote multiple times ${ }^{28}$.

It is worthwhile to emphasize the fact despite the nature, specie or morphology of electoral fraud as a phenomenon in

\footnotetext{
${ }^{26}$ Jeannette I. Andrade (2011-11-18). "Electoral sabotage case filed vs Arroyo, Ampatuan, Bedol”. Philippine Daily Inquirer. See, for example the National Voting Rights Institute report on New York State incarceration policies: [1].

${ }^{27}$ Layton, J., "How can someone tamper with an electronic voting machine". http://people.howstuffworks.com/vote-tampering.htm. Retrieved 2011-0227.

${ }^{28}$ Tom Feeble: 1977 , pp. 140-149.
}

emerging democracies. It needs to be checkmate and prevented. The concepts of secrecy and openness are used as too good preventive measures to checkmate electoral fraud. This is because it is well known ${ }^{29}$ the secret ballot system of voting prevents directly several incidents of voter intimidation, manipulation, vote selling, buying while openness of the entire electoral process by an independent and just electoral management body (such as the 2011 INEC in Nigeria under Professor Jega) not only helps to checkmate electoral fraud in its various ugly shades.

With respect to legislative electoral fraud open voting by legislators and covered by the media enhances the electoral integrity of legislative assemblies. It also increases the credible representative value of legislators as it ensures that they role in accordance with the wishes and interest of their constituencies who are watching their voting pattern in parliament. This particular transparency in legislative voting helped actually in checkmating the kind third ambition of Nigeria's former president Olusegun Obasanjo who wanted to bribe and manipulate the National Assembly with money to support his illegal tenure elongation project which is unconstitutional and unpopular in the country. The then president wanted to use voter fraud technique to win the votes of the Nigerian Senate and the House of Representatives for a tenure elongation which is not legally backed by Nigeria's constitution.

Generally speaking we may also factor election observation as part of the preventative measures to checkmate electoral fraud in general elections, especially in a new democracies. Essentially, election observers save the purpose of helping to identify areas where fraud could be perpetrated, sensitize its staff to stop and assure voters that they certify the election to be free, fair and transparent. For example part of the duties programs assigned and carried out by both local and international observers in the 2011 election in Nigeria was to prevent fraud in the central tabulation carried out by INEC came out with an open public list of results from all the polling booths and at the end of voting announced the result before the eagle eyes of observers, party agents and the voters. Nigerian legislatures at the local, state and national chambers may want also to experiment with domestic observation of its voting patterns to reduce the incidence of voter-buying, "Ghana must go" money spree and money for budget approvals from Federal Ministers.

\section{Conclusion}

The principle of one man, one woman one vote under girds the success of every democracy. In every election this principle is put to severe test and evaluation both by the people, election observers, monitors, and society groups and even those in the government who will participate in the election to test their popularity or unpopularity are agreed that electoral fraud either at the general election or in the legislature chambers truncates democracy, cheats the and demise them the dividends of both democracy and development. Electoral fraud has been identified as one of the most devastating reasons why Nigeria has remained poor in the midst of her abundant natural, human and mineral resources. This is why this article considers "electoral fraud as the worst form of corruption”"29. Before the 2011 April elections, various stakeholders and pillars of Nigeria's democracy attended a rally in Benin with the objective wring with the

\footnotetext{
${ }^{29}$ Youaltern: 30 April, 2011, Presidential Commitment to Electoral Reform Speech, Benin).
} 
best shategy of strengthening and stabilizing her democracy through electoral reforms. Electoral fraud was identified as the number one fundamental factor militating against eh emergence of a matured participatory and pro-people democracy in Nige$\mathrm{ria}^{30}$.

To checkmate and end the incidence of electoral fraud in Nigeria's democracy this article advocates more rigorous transparency, increased people participation in the pre-during, and post election phases in the future as well reflected and modeled by the new INEC under the leadership of Professor Attahiru Jega. The success of the 2011 Election in Nigeria was hailed locally and globally because they succeeded in reducing electoral fraud to the barest minimum, a clear departure from the past. Electoral Fraud in Nigeria could be further prevented and the integrity, transparency and credibility of our democracy enhanced with different globally tested and proven methods of prevention. Fraud prevention techniques could be summarised as "secrecy and openness". The secret ballot prevents many kinds of intimidation and vote selling, while transparency at all other levels of the electoral process prevents most interference. We can summarize some of the acceptable methods used in the developed democracies to checkmate the incidence of electoral fraud as: the secret ballot system of voting; transparency; statistical indicators or legal prosecution of culprits of voter frauds. We can also conclude this article with a brief rundown and analysis of the content of each methodology as follows:

\section{Secret Ballot}

The secret ballot, in which the general public does not know how individuals have voted, is a crucial part of ensuring free and fair election through preventing voter intimidation or retribution. Although it was sometimes practiced in ancient Greece and was a part of the French Constitution of 1795, it only became common in the nineteenth century. Secret balloting appears to have been first implemented in the former British colony-now an Australian state-of Tasmania on 7 February 1856. By the turn of the century the practice had spread to most Western democracies. Before this it was common for candidates to intimidate or bribe voters, as they always knew who had voted which way ${ }^{31}$.

\section{Transparency}

Most methods of preventing electoral fraud involve making the election process completely transparent to all voters, from nomination of candidates through casting of the votes and tabulation. A key feature in insuring the integrity of any part of the electoral process is a strict chain of custody. To prevent fraud in central tabulation, there has to be a public list of the results from every single polling place. This is the only way for voters to prove that the results they witnessed in their election office are correctly incorporated into the totals. In many cases, election observers are used to help prevent fraud and assure voters that the election is fair. International observers (bilateral and multilateral) may be invited to observe the elections ${ }^{32}$ (examples include election observation by the Organization for Security and Cooperation in Europe (OSCE), European Union

\footnotetext{
${ }^{30}$ Oshimole: April, 2011 Rally, Benin, Nigeria.

${ }^{31}$ Gill, K. "Help America Vote Act-HAVA".

http://uspolitics.about.com/od/elections/a/hava.htm Retrieved 2012-02-12.

${ }^{32}$ Johnston, Phillip; David Millward (Friday May 10, 1996). "Strategy to win votes topped lunch menu at Dame Shirley's”. The Daily Telegraph (London).
}

election observation missions, observation missions of the Commonwealth of Independent States (CIS), of the African Union as well as international and local observation organized by NGOs, such as European Network of Election Monitoring Organizations (ENEMO) of the Centre for Peacebuilding and Poverty Reduction (CEPPER)). This was particularly effective during Nigeria's 2011 Elections when INEC invited both foreign and domestic observer missions with NGOS to witness and monitor the integrity of the voting process to ensure transparency.

\section{Statistical Indicators}

Various forms of statistics can be indicators for election fraud e.g. exit polls which diverge from the final results. Wellconducted exit polls serve as a deterrent to electoral fraud. High numbers of invalid ballots, overvoting or undervoting are other potential indicators ${ }^{33}$.

\section{Prosecution}

In countries with strong laws and effective legal systems, lawsuits can be brought against those who have allegedly committed fraud; but determent with legal prosecution would not be enough. Although the penalties for getting caught may be severe, the rewards for succeeding are likely to be worth the risk. The rewards range from benefits in contracting to total control of a country. In Nigeria, calls for stiffer penalties for electoral fraud and malpractices have led to 2010 Electoral Law Reforms which have established INEC Electoral Tribunal to try and imprison violators and perpetrators of electoral fraud in Nigeria. This is what has worked in other electoral climes to stabilize democractic governance for development. It is therefore a combination of both prevention and deterrence strategies could reduce the incidence.

\section{REFERENCES}

Amy, M. (1994). The forgery of votes. Tower House Publication, Kingston.

Amy, M. (year). Frauding of elections. Tower House Publication, Kingston.

Kieshing, J. B. (year). Charting electoral fraud: Turnout distribution analysis as a tools for election assessment.

Legal Provisions to Prevent Electoral Fraud-An Article from the ACE Project.

Shilkin, S. (2010). The mathematics of elections. Turnbike Electoral Support Series.

Pat, U. (2011). National assembly is endangering our democracy. People Monthly.

Patrick, I. (2003). Electoral fraud and Nigeria’s 2003 Democratic quest (Part I). Alberts.

Thomas, B. (1994). Philosophical analysis and democratic concepts. Peer House Publication, India.

Voter Fraud (year) An article from the ACE Project.

Walter Mebane, (2011). Comparative election fraud detection. A TurnBike Electoral Report series.

\footnotetext{
${ }^{33}$ Saltman, Roy G. (January 2006). The History and Politics of Voting Technology. Palgrave Macmillan; 40-4.
} 